\title{
ANALISIS KADAR KARBOHIDRAT, VITAMIN C, $\beta$-KAROTEN DAN BESI (Fe) PADA BUAH KERSEN (Muntingia calabura L) SECARA SPEKTROFOTOMETRI UV-VIS
}

\author{
Aldrik M. Makahity ${ }^{1^{*}}$, Y. H. Dulanlebit ${ }^{1}$, Nazudin ${ }^{1}$ \\ ${ }^{1}$ Departement of Chemistry-FKIP, Pattimura University Ambon \\ *Aldrikmakahity@yahoo.com
}

Diterima 9 Agustus 2018/Disetujui 10 September 2018

\begin{abstract}
Kersen fruit (Muntingia calabura $\mathrm{L}$ ) is a fruit is existence found in everywhere, but generally nothing interest for consumtion almost people. In a kersen fruit contained many nutriet, aim from the study that is determine carbohydrate, vitamin $C, \beta$-caroten, and Fe levels in kersen fruit in the gain at Air Louw Village, Nusaniwe Subdistrict, Ambon City. In this study analize sample using spectrophotometry UV-Vis with wavelength carbohydrate $486 \mathrm{~nm}$, vitamin C $273 \mathrm{~nm}, \beta$-caroten $473 \mathrm{~nm}$ and Fe $474 \mathrm{~nm}$ and using technique calibration curve. Analyze result is showed that carbohydrate level by $343,393 \mathrm{mg} / 100 \mathrm{~g}$, vitamin $\mathrm{C}$ level by $178,96 \mathrm{mg} / 100 \mathrm{~g}$, $\beta$-caroten level by $1,4831 \mathrm{mg} / 100 \mathrm{~g}$, and Fe levels by $0,1025 \mathrm{mg} / 100 \mathrm{~g}$. Based result study can conclusion if kersen fruit can be consumption as food material because having nutrient contet enough for human's body.
\end{abstract}

Keywords: Kersen fruit (Muntingia calabura L), Carbohydrate, Vitamin C, $\beta$-caroten, Iron (Fe), Spectrophotometry UV-Vis

\begin{abstract}
ABSTRAK
Buah kersen (Muntingia calabura L) merupakan buah yang keberadaanya sering kita jumpai dimana-mana, namun pada umumnya kurang diminati untuk dikunsumsi oleh sebagian orang. Dalam buah kersen mengandung banyak kandungan gizi. Tujuan dari penelitian ini yaitu untuk menentukan kadar karbohidrat, vitamin $C, \beta-$ karoten dan Besi ( $\mathrm{Fe}$ ) pada buah kersen yang diperoleh dari Desa Air Louw, Kecamatan Nusaniwe, Kota Ambon. Pada penelitian ini Sampel dianalisis menggunakan spektrofotometri UV-Vis dengan panjang gelombang karbohidrat $486 \mathrm{~nm}$, vitamin C $273 \mathrm{~nm}$, $\beta$-karoten $473 \mathrm{~nm}$ dan Fe $474 \mathrm{~nm}$ dan menggunakan teknik kurva kalibrasi. Hasil analisis menunjukan bahwa kadar karbohidrat sebesar 343,393 mg/100gram, vitamin $\mathrm{C}$ sebesar $178,96 \mathrm{mg} / 100 \mathrm{~g}, \beta$-karoten 1,4831 mg/100 g, dan Fe sebesar 0,1025 mg/100 g. Berdasarkan hasil penelitian dapat disimpulkan bahwa buah kersen dapat dikonsumsi sebagai bahan pangan karena memiliki kandungan gizi yang cukup bagi tubuh manusia.
\end{abstract}

Kata Kunci: Buah kersen (Muntingia calabura L), Karbohidrat, Vitamin C, $\beta$-Karoten, Besi (Fe), Spektrofotometri UV-Vis

\section{PENDAHULUAN}

Pangan merupakan kebutuhan dasar manusia, sehingga ketersediaannya harus dalam jumlah yang cukup, bergizi dan terjangkau daya beli oleh masyarakat (Nurmala, 1997). Nilai gizi yang terkandung dalam bahan pangan berguna untuk memberikan energi, mengatur pertumbuhan, mengatur jaringan dan mekanisme tubuh. Berbagai zat gizi yang terkandung dalam bahan pangan, antara lain: protein, karbohidrat, vitamin dan mineral yang merupakan nutrisi penting bagi pertumbuhan tubuh. 
Karbohidrat merupakan senyawa yang terbentuk dari molekul karbon, hidrogen dan oksigen. Sebagai zat gizi, fungsi utama karbohidrat adalah sebagai penghasil energi dalam proses metabolisme tubuh. Hasil metabolisme antara lain glukosa yang terdapat dalam darah, sedangkan glikogen merupakan karbohidrat yang disintesis dalam hati. Amilum, selulosa, glikogen, sukrosa dan glukosa merupakan karbohidrat yang terpenting dalam kehidupan manusia (Poedjidi dan Supriyanti, 2009).

Vitamin $C$ adalah salah satu zat gizi yang berperan sebagai antioksidan dan efektif mengatasi radikal bebas yang dapat merusak sel atau jaringan. Status vitamin $C$ seseorang sangat tergantung dari usia, jenis kelamin, asupan vitamin $C$ harian serta adanya penyakit tertentu (Schetman, 1989).

$\beta$-karoten adalah senyawa dengan aktivitas vitamin $A$ yang terdapat dalam tanaman yang termasuk dalam kelompok karotenoid. $\beta$-karoten akan diubah menjadi vitamin A pada proses metabolisme tubuh setelah dikonsumsi oleh manusia atau hewan (Andarwulan dan Koswara, 1992). Cincin $\beta$ dari $\beta$ karoten didalam tubuh akan diubah menjadi vitamin $A$ oleh enzim karoten oksigenase menjadi 2 molekul retinal kemudian retinal direduksi menjadi 2 retinol dengan adanya enzim alkohol dihidrogenase dan kemudian disimpan di hati (de Fretes, dkk, 2012).

Besi merupakan unsur mikro yang berfungsi dalam produksi hemoglobin $(\mathrm{Hb})$ dan merupakan bagian dari enzim oksidatif, dalam transportasi dan pendayagunaan oksigen. Hemoglobin adalah ikatan antara protein, Fe dan zat warna. $60 \%$ dari Fe yang ada dalam tubuh manusia terdapat dalam hemoglobin (Ariyani dkk, 2011). Dalam tanaman, unsur Fe merupakan bagian dari penyusun sitokrom dan leghaemoglobin yang sangat penting dalam proses respirasi dan fotosintesis. Unsur ini juga merupakan unsur yang sangat penting dalam mengatur kerja enzim yang terlibat dalam sintesis klorofil (Widyati, 2011).

Fungsi buah-buahan sangat penting bagi proses metabolisme tubuh karena banyak mengandung vitamin serat mineral (Poerwanto, 2004). Salah satu buah yang memiliki kandungan zat gizi yang tinggi yaitu buah kersen. Menurut penelitian yang dilakukan oleh Dwi (2010), menunjukkan bahwa hasil analisis dengan menggunakan instrumen UV-Vis dan AAS dalam 100 gram buah kersen terkandung : air $(77,8 \mathrm{~g})$, protein $(0,384 \mathrm{~g})$, lemak $(1,56 \mathrm{~g})$, karbohidrat $(17,9 \mathrm{~g})$, kalsium (124,6 mg), fosfor (84 mg), besi $(1,18 \mathrm{mg})$, vitamin C (80,5 mg) dan vitamin A $(0,015 \mathrm{mg})$. Menurut Verdayanti (2009), buah kersen merupakan salah satu tanaman yang diduga memiliki substansi aktif sebagai antidiabetes dalam penelitiannya tentang uji efektifitas jus buah kersen terhadap penurunan kadar glukosa darah pada tikus putih (Rattus norvegicus) menunjukkan bahwa jus buah kersen berpengaruh dalam menurunkan glukosa darah. Pengujian terbaiknya yaitu dengan 4 doisis $\mathrm{mL}$ jus buah kersen dapat menurunkan glukosa darah.

Berdasarkan hasil-hasil penelitian tersebut, didapatkan bahwa buah kersen mengandung nilai gizi cukup tinggi, oleh sebab itu mengkonsumsi bahan makanan yang mengandung gizi sangatlah penting. Namun kurangnya pengetahuan tentang kandungan zat gizi dalam buah kersen mengakibatkan buah ini kurang diminati oleh masyarakat, terkhususnya masyarakat Maluku. Masyarakat mengangap bahwa tanaman ini tidak begitu bermanfaat sehingga buah ini dibiarkan membusuk dan dibuang. Berdasarkan masalah di atas maka perlu dilakukan penelitian tentang kadar karbohidrat, vitamin $\mathrm{C}, \beta$-Karoten dan Fe pada buah kersen (Muntingia Calabura $L$ ) yang terdapat di daerah Maluku.

\section{METODE PENELITIAN}

Sampel yang digunakan adalah buah kersen (Muntingia calabura $L$ ) yang di peroleh dari Desa Air Louw, Kecamatan Nusaniwe, Kota Ambon. 


\section{Alat dan Bahan}

Dalam penelitian ini sampel di gunakan menggunakan instrument Spektrofotometer UV-Vis merk Raylegh UV-9200, bahan yang digunakan yaitu $\beta$-karoten murni 1000 ppm, larutan glukosa 1000 ppm, asam askorbat 1000 ppm, dan larutan standar Fe 1000 ppm, Etanol p.a, Aquades, Kertas saring whatmen No.42, n-heksana, Larutan $\mathrm{Na}_{2} \mathrm{~S}_{2} \mathrm{O}_{3} 100$ ppm, Silika gel, 1,10 fenantrolin 1000 ppm, Indikator universal, Natrium sulfat anhidrid, Buffer asetat, $\mathrm{HCl} 1,0 \mathrm{M}$, Aseton, $\mathrm{NaOH} 5 \%$, Magnesium karbonat, Larutan Fenol 5\%, Larutan $\mathrm{H}_{2} \mathrm{SO}_{4}$.

\section{Prosedur kerja}

\section{a. Kadar Air}

Sampel buah kersen ditimbang kemudian dimasukkan ke dalam cawan porselin yang telah diketahui bobotnya dan dipanaskan di dalam oven pada suhu $80^{\circ} \mathrm{C}$ sampai beratnya konstan. Cawan dikeluarkan dari oven dan didinginkan dalam desikator kemudian ditimbang beratnya dan diukur kadar airnya.

\section{b. Persiapan Sampel Buah Kersen}

\section{- Karbohidrat}

Buah kersen yang telah diambil, dicuci sampai bersih dan dikeringkan pada suhu ruang kemudian dihaluskan. Sampel yang telah halus diambil sebanyak $5 \mathrm{~g}$ dimasukan ke dalam Erlenmeyer kemudian ditambahkan $100 \mathrm{~mL}$ akuades serta $100 \mathrm{~mL} \mathrm{HCl} \mathrm{1,0} \mathrm{M,} \mathrm{dan} \mathrm{dipanaskan}$ selama 1-2 jam untuk memecahkan karbohidrat menjadi gula sederhana (glukosa). Selanjutnya larutan reaksi, di dinginkan sampai mencapai suhu kamar, dan larutan dinetralkan dengan $\mathrm{NaOH}$ $50 \%$ hingga mencapai $\mathrm{pH}$ netral. Campuran kemudian dipanaskan selama 1 jam setelah itu didinginkan. Selanjutnya campuran disaring dengan kertas saring agar fitrat yang diperoleh benarbenar jernih, setelah itu larutan diencerkan di dalam labu takar $500 \mathrm{~mL}$, kemudian dipipet $1 \mathrm{~mL}$ dan dimasukkan dalam tabung Ditambahkan $1 \mathrm{~mL}$ larutan fenol $5 \%$ ke dalam tabung dan $5 \mathrm{~mL} \mathrm{H}_{2} \mathrm{SO}_{4}$ melalui dinding tabung reaksi sampai terbentuk warna jingga kekuningan pada larutan sampel. Kemudian tabung dipanaskan dalam penangas air selama 10 menit pada suhu $60{ }^{\circ} \mathrm{C}$, kemudian didinginkan sampai mencapai suhu kamar, lalu dianalisis menggunakan spektrofotometri UV-Vis (Karepesina, 2012).

\section{- Vitamin C}

Sampel buah kersen dibersihkan kemudian ditimbang sebanyak $50 \mathrm{~g}$ dan dihaluskan dengan blender, diambil cairannya lalu disaring. Setelah itu filtratnya dimasukkan ke dalam labu takar 100 $\mathrm{mL}$ dan ditambahkan akuades sampai tanda batas kemudian dihomogenkan, kemudian dianalisis menggunakan spektrofotometri UV-Vis (Oktaviani dkk, 2014).

\section{- $\beta$-karoten}

Sampel buah kersen dibersihkan kemudian dihaluskan dan ditimbang sebanyak $50 \mathrm{~g}$, kemudian diekstrak dengan campuran pelarut aseton:n-heksana (4:6) sebanyak $100 \mathrm{~mL}$, dan 0,1 g magnesium karbonat kemudian diaduk menggunakan shaker pada $350 \mathrm{rpm}$ selama 30 menit, disaring, residu dicuci dengan aseton:n-heksana (1:1) sebanyak $30 \mathrm{~mL}$, dan dicuci lagi dengan $10 \mathrm{~mL}$ aquades. Ekstrak kasar yang diperoleh kemudian ditampung (terbentuk dua fasa, fasa organik dan fasa air). Kemudian kedua fasa ini dipindahkan menggunakan corong pisah. Aseton dari ekstrak dipisahkan, sedangkan fasa organik diambil untuk dianalisis selanjutnya. Fasa organik dipindahkan ke dalam erlenmeyer $100 \mathrm{~mL}$, divakum untuk menghilangkan sisa pelarut pada suhu $30^{\circ} \mathrm{C}$, dan didapatkan ekstrak berwarna kuning kehijauan. Kolom kromatografi disiapkan dengan panjang kolom $40 \mathrm{~cm}$ dengan adsorben silika gel dengan tinggi $20 \mathrm{~cm}$, lapisan natrium sulfat anhidrid ditempatkan setinggi $5 \mathrm{~cm}$ di atas lapisan silika gel. Ekstrak pigmen yang didaptkan, dimasukan kedalam kolom secara perlahan, dielusi dengan menggunakan pelarut aseton:n-heksan (1:9) sebanyak $100 \mathrm{~mL}$, selama 
proses elusi dijaga supaya lapisan atas selalu terisi dengan pelarut. $\beta$-karoten akan melewati kolom secara cepat. Pita klorofil yang berwarna hijau akan teradopsi dalam kolom, hasil elusi $\beta$-karoten (warna kuning) dikumpulkan dalam erlenmeyer $100 \mathrm{~mL}$ dan diukur volume ekstrak yang dihasilkan. Kemudian diukur absorbansinya menggunakan spektrofotometer UV-Vis.

- Besi (Fe)

Buah kersen yang telah diambil, dicuci sampai bersih dan dikeringkan pada suhu ruang kemudian dihaluskan. Sampel yang telah dihaluskan ditimbang sebanyak $5 \mathrm{~g}$ kemudian didestruksi menggunakan $\mathrm{HCl}$ pekat sebanyak $20 \mathrm{mLselama} 2$ jam pada suhu $90{ }^{\circ} \mathrm{C}$. Larutan didinginkan kemudian disaring. Filtrat dimasukan Kedalam labu takar $25 \mathrm{~mL}$ kemudian dilarutkan dengan akuades hingga tanda batas. Larutan hasil preparasi diambil 0,1 $\mathrm{mL}$ dan dimasukkan ke dalam labu ukur $10 \mathrm{~mL}$ kemudian direaksikan dengan 1,1 mL Na $\mathrm{S}_{2} \mathrm{O}_{3} 100 \mathrm{ppm}, 1,5 \mathrm{~mL}$ larutan1,10 fenantrolin $1000 \mathrm{ppm}$, dan $1,5 \mathrm{~mL}$ buffer asetat $\mathrm{pH} 4,5$ setelah itu ditambahkan aseton $5 \mathrm{~mL}$ dan akuades hingga tanda batas dan didiamkan selama 120 menit, kemudian dianalisis menggunakan spektrofotometri UV-Vis (Dianawati Novi, 2015).

\section{c. Penentuan Panjang Gelombang Maksimum Karbohidrat, Vitamin C, $\beta$-karoten dan Fe}

Dipipet masing-masing $4 \mathrm{~mL}$ larutan glukosa, larutan asam askorbat, larutan $\beta$-karoten dan larutan Fe 100 ppm dimasukkan masing-masing ke dalam labu takar $20 \mathrm{~mL}$. Lalu ditambahkan akuades sampai tanda batas dan dihomogenkan. Diukur serapan maksimum masing-masing pada panjang gelombang 400-800 nm untuk karbohidrat, Fe dan $\beta$-karoten dan panjang gelombang 200$400 \mathrm{~nm}$ untuk vitamin $C$ dengan menggunakan blanko akuades dan aseton:n-heksan (1:9) untuk $\beta$ karoten.

\section{d. Pembuatan Deret Larutan standar}

\section{- Deret larutan standar glukosa 100 ppm}

Larutan standar glukosa 100 ppm dibuat dengan mengambil larutan induk glukosa 1000 ppm sebanyak $10 \mathrm{~mL}$, kemudian diencerkan dalam labu takar $100 \mathrm{~mL}$ dengan akuades hingga tanda batas. Selanjutnya dibuat deret larutan standar karbohidrat dengan konsentrasi 0,$0 ; 4,0 ; 8,0$; 12,$0 ; 16,0$ dan 20,0 ppm, untuk konsentrasi 0,0 ppm hanya digunakan blanko sedangkan untuk deret standar 4,0; 8,0; 12,0; 16,0 dan 20,0 ppm dibuat dengan cara mengambil 4,0; 8,0;12,0; 16,0 dan $20,0 \mathrm{~mL}$ dari larutan standar karbohidrat $100 \mathrm{ppm}$ kemudian diencerkan dalam labu takar $100 \mathrm{~mL}$ dengan akuades hingga tanda batas.

\section{- Deret larutan standar Vitamin C 100 ppm}

Larutan standar vitamin C $1000 \mathrm{ppm}$ dibuat dengan cara menimbang $0,1 \mathrm{~g}$ asam askorbat, kemudian diencerkan dalam labu takar $100 \mathrm{~mL}$ dengan akuades hingga tanda batas. Selanjutnya larutan standar vitamin C 100 ppm dibuat dengan mengambil $10 \mathrm{~mL}$ dari larutan standar vitamin C 1000 ppm, kemudian diencerkan dalam labu takar $100 \mathrm{~mL}$ dengan akuades hingga tanda batas. Selanjutnya dibuat deret larutan standar vitamin $C$ dengan konsentrasi 0,$0 ; 4,0 ; 8,0 ; 12,0 ; 16,0$ dan $20,0 \mathrm{ppm}$, untuk konsentrasi $0,0 \mathrm{ppm}$ hanya digunakan blanko sedangkan untuk deret standar 4,0; 8,$0 ; 12,0 ; 16,0$ dan 20,0 ppm dibuat dengan cara mengambil 4,0; 8,0;12,0;16,0 dan 20,0 mL dari larutan standar vitamin C 100 ppm kemudian diencerkan dalam labu takar $100 \mathrm{~mL}$ dengan akuades hingga tanda batas.

\section{- Deret larutan standar $\beta$-karoten 100 ppm}

Larutan standar $\beta$-karoten $1000 \mathrm{ppm}$ dibuat dengan cara menimbang $0,1 \mathrm{~g} \beta$-karoten, kemudian diencerkan dalam labu takar $100 \mathrm{~mL}$ dengan aseton:n-heksan(1:9). Selanjutnya larutan standar $\beta$ karoten $100 \mathrm{ppm}$ dibuat dengan mengambil $10 \mathrm{~mL}$ dari larutan standar $\beta$-karoten $1000 \mathrm{ppm}$, kemudian diencerkan dalam labu takar $100 \mathrm{~mL}$ dengan aseton:n-heksan (1:9) hingga tanda batas. 
Selanjutnya dibuat deret larutan standar $\beta$-karoten dengan konsentrasi 0,$0 ; 2,0 ; 4,0 ; 6,0 ; 8,0$ dan 10,0 ppm, untuk konsentrasi 0,0 ppm hanya digunakan blanko sedangkan untuk deret standar 2,0; 4,0; 6,0; 8,0 dan 10,0 ppm dibuat dengan cara mengambil 2,0; 4,0; 6,0; 8,0 dan 10,0 mL dari larutan standar $\beta$-karoten 100 ppm kemudian diencerkan dalam labu takar $100 \mathrm{~mL}$ dengan aseton:n-heksana (1:9) hingga tanda batas.

\section{- Deret larutan standar Besi (Fe) 100 ppm}

Larutan standar Fe 100 ppm dibuat dengan mengambil $10 \mathrm{~mL}$ dari larutan induk Fe 1000 ppm, kemudian diencerkan dalam labu takar $100 \mathrm{~mL}$ dengan akuades hingga tanda batas. Selanjutnya dibuat deret larutan standar besi dengan konsentrasi 0,$0 ; 0,25 ; 0,5 ; 0,75 ; 1,0 ; 1,25$ dan $1,50 \mathrm{ppm}$, untuk konsentrasi $0,0 \mathrm{ppm}$ hanya digunakan blanko sedangkan untuk deret standar 0,$25 ; 0,5 ; 0,75$; 1,$0 ; 1,25$ dan $1,50 \mathrm{ppm}$ dibuat dengan cara mengambil 0,$25 ; 0,5 ; 0,75 ; 1,0 ; 1,25$ dan $1,50 \mathrm{~mL}$ dari larutan standar Fe 100 ppm kemudian diencerkan dalam labu takar $100 \mathrm{~mL}$ dengan akuades hingga tanda batas.

\section{e. Penentuan absorbansi standar dan sampel}

Larutan standar karbohidrat, Fe, vitamin C, $\beta$-karoten serta sampel buah kersen (Muntingia calabura L) yang telah dipreparasi diukur absorbansinya dengan menggunakan spektrofotometri UVVis. pengukuran absorbansi dilakukan pada panjang gelombang maksimum.

\section{Analisis Data}

Berdasarkan data hasil pengukuran larutan standar dan larutan sampel, dibuat kurva standar untuk memperoleh hubungan antara absorbansi $(y)$ dan konsentrasi $(x)$. Persamaan regresi dari hubungan antara absorbansi dan konsentrasi dapat digunakan dengan persamaan:

$$
y=a x+b
$$

dimana, $\mathrm{x}=$ konsentrasi, $\mathrm{y},=$ absorbansi, $\mathrm{a}=$ slope, $\mathrm{b}=$ intersep (Dewi, 2012: 15).

Konsentrasi yang diperoleh dari kurva ini merupakan konsentrasi dalam satuan mg/L. Sedangkan sampel yang digunakan untuk dianalisis, kadarnya dalam $\mathrm{mg} / \mathrm{Kg}$. Untuk menghitung kadar karbohidrat, vitamin $\mathrm{C}, \beta$-karoten, dan $\mathrm{Fe}$ dalam satuan $\mathrm{mg} / \mathrm{Kg}$ berat sampel dapat menggunakan perumusan:

$$
\frac{\mathrm{mg}}{\mathrm{kg}}=\frac{\text { konsentrasi }\left(\frac{\mathrm{mg}}{\mathrm{L}}\right) \times \text { volume sampel }(\mathrm{L}) \mathrm{x} \mathrm{FP}}{\text { berat sampel }(\mathrm{kg})}
$$

(Pardede dkk, 2013: 165).

\section{HASIL PENELITIAN}

\section{A. Kadar Air}

Sebelum dilakukan analisis karbohidrat, vitamin $\mathrm{C}, \beta$-karoten dan Fe pada buah kersen terlebih dahulu dilakukan penentuan kadar air. Penentuan kadar air pada penelitian ini dilakukan secara termogravimetri (pengeringan) dimana buah kersen dipanaskan selama 24 jam pada suhu $80{ }^{\circ} \mathrm{C}$. Selain mudah pengerjaanya metode ini digunakan karena karakter sampel tidak mengandung komponen-komponen yang mudah menguap (Apriyantono, 1989). Kadar air yang terdapat dalam buah kersen yang di ambil pada Desa Air Louw adalah 75\% (Lampiran 1). Kadar air sangat penting 
pada bahan pangan, karena air dapat mempengaruhi tekstur, dan citarasa pada bahan pangan. Kadar air dalam bahan pangan ikut menentukan kesegaran dan daya awet bahan pangan tersebut, kadar air yang tinggi mengakibatkanmudahnya bakteri untuk berkembang biak, sehingga akan terjadi perubahan pada bahan pangan (Winarno, 1997).

\section{B. Kadar Karbohidrat}

Data hasil analisis kadar karbohidrat pada buah kersen (Muntingia calabura L) dengan menggunakan spektrofotometer UV-Vis dapat dilihat pada Table 1.

Tabel 1. Hasil Analisis Kadar Karbohidrat pada Sampel Buah Kersen

\begin{tabular}{cccccc}
\hline Sampel & $\begin{array}{c}\text { Absorbansi } \\
\text { (A) }\end{array}$ & $\begin{array}{c}\text { Konsentrasi } \\
\text { Karbohidrat } \\
\text { (mg/L) }\end{array}$ & $\begin{array}{c}\text { Kadar } \\
\text { karbohidrat } \\
\text { (mg/Kg) }\end{array}$ & $\begin{array}{c}\text { Rata-rata } \\
\text { kadar } \\
\text { karbohidrat } \\
\text { (mg /Kg) }\end{array}$ & $\begin{array}{c}\text { Rata-rata } \\
\text { kadar } \\
\text { karbohidrat } \\
\text { (mg/100 g) }\end{array}$ \\
\hline P.1 & 0,079 & 17,466 & 34932 & & \\
P.2 & 0,080 & 17,688 & 35376 & 34339,33 & 343,393 \\
P.3 & 0,074 & 16,355 & 32710 & & \\
\hline
\end{tabular}

Berdasarkan data hasil analisis diperoleh kadar karbohidrat pada buah kersen sebesar 343,393 $\mathrm{mg} / 100 \mathrm{~g}$. Kandunganya sangat tinggi jika dibandingkan dengan penelitian Dwi (2010). Perbedaan lokasi pengambilan sampel dapat mempengaruhi kadar karbohidrat dalam buah dimana setiap lokasi memiliki karakteristik tersendiri serta perbedaan kondisi air dan juga unsur hara dalam tanah yang sangat mempengaruhi kadar meneral dalam buah. Unsur hara dalam tanah diserap oleh akar tanaman. Akar tanaman berhubungan langsung dengan partikel koloid dalam tanah dan tiap-tiap partikel koloid tanah dilapisi oleh lapisan yang mengandung mineral terlarut, mineral-mineral terlarut tersebut akan dibagikan ke seluruh anggota tubuh tumbuhan sehingga mineral dalam tanah, berada juga dalam tubuh tumbuhan (Susilowati dkk, 2008).

\section{Vitamin C}

Data hasil analisis kadar vitamin C pada buah kersen (Muntingia calabura L) dengan menggunakan spektrofotometer UV-Vis dapat dilihat pada Table 2.

Tabel 2. Hasil Analisis Kadar Vitamin C pada Sampel Buah Kersen

\begin{tabular}{cccccc}
\hline Sampel & $\begin{array}{c}\text { Absorbansi } \\
\text { (A) }\end{array}$ & $\begin{array}{c}\text { Konsentrasi } \\
\text { vitamin C } \\
(\mathbf{m g} / \mathbf{L})\end{array}$ & $\begin{array}{c}\text { Kadar } \\
\text { vitamin C } \\
(\mathbf{m g} / \mathbf{K g})\end{array}$ & $\begin{array}{c}\text { Rata-rata } \\
\text { kadar } \\
\text { vitamin C } \\
(\mathbf{m g} / \mathbf{K g})\end{array}$ & $\begin{array}{c}\text { Rata-rata } \\
\text { kadar } \\
\text { vitamin C } \\
(\mathbf{m g} / \mathbf{1 0 0} \mathbf{~ g})\end{array}$ \\
\hline P.1 & 0,308 & 8,997 & 17994 & & \\
P.2 & 0,304 & 8,880 & 17760 & 17896,6 & 178,96 \\
P.3 & 0,307 & 8,968 & 17936 & & \\
\hline
\end{tabular}

Kadar vitamin C pada penelitian ini hasilnya lebih tinggi dibandingkan dengan penelitian sebelumnya yang dilakukan Dwi (2010). Perbedaan kadar disebabkan oleh pengaruh tempat tumbuh atau faktor lingkungan yaitu faktor iklim dan tanah. Jika lokasi tumbuh sampel berada di daerah dengan intensitas cahaya yang tinggi dan mendapat banyak sinar matahari maka kandungan vitamin C lebih tinggi dibandingkan dengan buah yang tanamanya kurang memperoleh sinar matahari (Cahyono, 2010). 


\section{Kadar $\beta$-karoten}

Data hasil analisis kadar $\beta$-karoten pada buah kersen (Muntingia calabura L) dengan menggunakan spektrofotometer UV-Vis dapat dilihat pada Table 3.

Tabel 3. Hasil Analisis Kadar $\beta$-karoten pada Sampel Buah Kersen

\begin{tabular}{|c|c|c|c|c|c|}
\hline Sampel & $\begin{array}{c}\text { Absorbansi } \\
\text { (A) }\end{array}$ & $\begin{array}{c}\text { Konsentrasi } \\
\beta \text {-karoten } \\
\text { (mg/L) }\end{array}$ & $\begin{array}{c}\text { Kadar } \beta- \\
\text { karoten } \\
(\mathbf{m g} / \mathrm{Kg})\end{array}$ & $\begin{array}{c}\text { Rata-rata } \\
\text { kadar } \beta- \\
\text { karoten } \\
(\mathrm{mg} / \mathrm{Kg})\end{array}$ & $\begin{array}{c}\text { Rata-rata } \\
\text { kadar } \beta- \\
\text { karoten } \\
(\mathrm{mg} / 100 \mathrm{~g})\end{array}$ \\
\hline P.1 & 0,080 & 7,3853 & 147,706 & & \\
\hline P.2 & 0,079 & 7,2935 & 145,87 & 148,3173 & 1,4831 \\
\hline P.3 & 0,082 & 7,5688 & 151,376 & & \\
\hline
\end{tabular}

Berdasarkan data di atas ternyata kadar $\beta$-karoten yang didapat lebih tinggi dibandingkan dengan penelitian sebelumnya Dwi (2010) dan Verneij dan Coronel (1997). Perbedaan ini dipengaruhi oleh tingkat kematangan sampel, semakin merah buah kersen maka kadar $\beta$-karotennya semakin tinggi. Dengan demikian faktor pemanenan atau pengambilan sampel sangat menentukan kadar $\beta$-karoten. Selain itu juga perbedaan lokasi pengambilan sampel dapat mempengaruhi kadar $\beta$-karoten, karena setiap lokasi memiliki karakteristik tersendiri serta perbedaan unsur hara di dalam tanah. Fungsi $\beta$-karoten dalam tubuh manusia yaitu sebagai antioksidan selain itu $\beta$-karoten juga dapat mencegah penyakit seperti strok, jantung coroner dan kanker (Palupiu dan Martosupono, 2009). Karena mengandung $\beta$-karoten, maka buah kersen dapat dijadikan sebagai sumber $\beta$ karoten, untuk memenuhi kebutuhan pangan manusia.

\section{E. Kadar Besi (Fe)}

Data hasil analisis kadar Besi (Fe) pada buah kersen (Muntingia calabura L) dengan menggunakan spektrofotometer UV-Vis dapat dilihat pada Table 4.

Tabel 4. Hasil Analisis Kadar Fe pada Sampel Buah Kersen

\begin{tabular}{|c|c|c|c|c|c|}
\hline Sampel & $\begin{array}{c}\text { Absorbansi } \\
\text { (A) }\end{array}$ & $\begin{array}{c}\text { Konsentrasi } \\
\text { besi (Fe) } \\
\text { (mg/L) }\end{array}$ & $\begin{array}{c}\text { Kadar } \\
\text { besi (Fe) } \\
(\mathrm{mg} / \mathrm{Kg})\end{array}$ & $\begin{array}{c}\text { Rata-rata } \\
\text { kadar besi } \\
(\mathrm{Fe}) \\
(\mathrm{mg} / \mathrm{Kg})\end{array}$ & $\begin{array}{c}\text { Rata-rata } \\
\text { kadar besi } \\
(\mathrm{Fe}) \\
(\mathrm{mg} / 100 \mathrm{~g})\end{array}$ \\
\hline P.1 & 0,079 & 0,5060 & 10,12 & & \\
\hline P.2 & 0,081 & 0,5196 & 10,392 & 10,256 & 0,1025 \\
\hline P.3 & 0,080 & 0,5128 & 10,256 & & \\
\hline
\end{tabular}

Berdasarkan data di atas didapatkan kadar Fe dalam buah kersen cukup tinggi yaitu 0,1025 $\mathrm{mg} / 100 \mathrm{~g}$ atau dalam $1 \mathrm{~kg}$ bahan pangan yakni 10,256 mg/kg dibandingkan dengan penelitian oleh Noya (2015) untuk daerah Ambon yakni 9,1322 mg/Kg, hal ini disebabkan karena masing-masing lokasi memiliki kandungan zat berbeda. Jiika lokasinya berada dekat aliran sungai biasanya kadar besi rendah, hal ini disebabkan karena tanahnya memiliki kandungan air yang banyak dan menyebabkan besi teroksidasi sehingga kandungan besinya rendah (Susilo, 1991). Reaksi oksidasi besi oleh air dapat dilihat sebagai berikut:

$$
\mathrm{Fe}^{2+}{ }_{(\mathrm{aq})}+3 \mathrm{H}_{2} \mathrm{O}_{(\mathrm{l})} \longrightarrow \mathrm{Fe}(\mathrm{OH})_{3(\mathrm{aq})}+3 \mathrm{H}^{+}{ }_{(\mathrm{aq})}+\mathrm{e}^{-}
$$


Mengkonsumsi buah kersen sangatlah penting karena zat besi tergolong unsur mikro yang berperan untuk memproduksi sel darah merah atau hemoglobin dan sebagai enzim oksidatif untuk mengatur metabolisme protein dan bekerja sama dengan zat lain untuk memelihara kesehatan (Ariyani dkk, 2011). Menurut Widya Karya Nasional Pangan Dan Gizi (WKNPG) kebutuhan zat besi (Fe) seseorang/hari adalah $26 \mathrm{mg}$ untuk wanita dan $13 \mathrm{mg}$ untuk pria. Berdasarkan data tersebut maka buah kersen dapat dapat meberikan asupan mineral besi yang cukup untuk tubuh.

\section{KESIMPULAN}

Berdasarkan hasil penelitian yang telah dilakukan maka dapat disimpulkan bahwa kadar karbohidrat, vitamin $\mathrm{C}, \beta$-karoten dan besi $(\mathrm{Fe})$ pada buah kersen (Muntingia calabura $\mathrm{L}$ ) yang diperoleh dari Desa Air Louw, Kecamatan Nusaniwe, Kota Ambon masing-masing 343,393 mg/100 $\mathrm{g}, 178,96 \mathrm{mg} / 100 \mathrm{~g}, 1,4831 \mathrm{mg} / 100 \mathrm{~g}$ dan $0,1025 \mathrm{mg} / 100 \mathrm{~g}$. Dengan demikian buah kersen dapat dijadikan sebagai pangan lokal karena memiliki kandungan gizi yang cukup oleh sebab itu mengkonsumsi buah kersen sangatlah baik bagi tubuh manusia.

\section{DAFTAR PUSTAKA}

Andarwulan, N, dan Koswara, S. 1992. Kimia Vitamin. Jakarta: Rajawali Pres.

Ariyani, W. D, dkk. (2011). Aplikasi teknik aan dan ssa dalam penentuan nilai asupan harian unsur $\mathrm{Ca}, \mathrm{Fe}$, dan $\mathrm{Zn}$ pada anak usia sekolah di kota bandung. Jurnal sains dan teknologinuklir Indonesia, 12,95-104.

de Fretes, H., Susanto, A. B., Prasetyo, B., dan Limantara, L. (2012). Karotenoid dari Makroalgae dan Mikroalgae: Potensi Kesehatan Aplikasi dan Bioteknologi. Jurnal Teknologi dan Industri Pangan, 23(2), 221-228, DOI: 10.6066/jtip.2012.23.2.221

Noya Fresly. 2015. Analisis Kadar Fe dan Ca pada buah Kersen (Muntingia calabura L). Skripsi. Program Studi Pendidikan Kimia. Unpatti. Ambon

Nurmala, T. 1997. Serealia Sumber Karbohidrat Utama. Jakarta: Penerbit Rineka Putra.

Pardede, B. E, Adhitiyawarman, dan Arreneuz, S. (2013). Pemanfaatan enzim papain dari getah buah pepaya (Carica Papaya $L$ ) dalam pembuatan keju cottage menggunakan bakteri Lactobacillus Bulgaricus. Jkk, 2, 163-168.

Poerwanto, R. 2004. Pembangunan Sentra Produksi Buah berbasis Mutu. Penebar Swadaya: Jakarta.

Poedjidi, dan Supriyanti. 2009, Dasar-dasar Biokimia. Jakarata: Penerbit Universitas Indonesia (UIPress).

Schetman, G. 1989. The Influence of Smoking on Vitamin C Status In Adult. Am. J. Publick Health. 79,158-162.

Sumardi. 1981. Metode Destruksi Contoh Secara Kering Dalam Analisis Unsur-Unsur Fe-Cu-Mn dan $\mathrm{Zn}$ dalam contoh-contoh Biologis. Prosending Seminar Nasional Metode Analisis. Lembaga Kimia Nasional. Jakarta: LIPI.

Susilowati, dkk. 2008. Flora Eksotika Tanaman Peneduh. Kanisius: Yogyakarta.

Widyati, E. (2011). Optimalisasi pertumbuhan Acaceia Crassicarpa CUNN. EX BENTH pada tanah bekas tambang batu bara dengan ameliorasi tanah. Jurnal penelitian hutan tanaman, 8 , 19-30.

Winanrno F.G. 2007. Kimia Pangan dan Gizi. Jakarta: Gramedia Pustaka Utama.

Winanrno F.G. 2004. Kimia Pangan dan Gizi. Jakarta: Gramedia Pustaka Utama 